\title{
Study On Application Of Alumina In High-Purity Andalusite Based Refractory
}

\author{
Guihua Liao ${ }^{1}$, Keying $\mathrm{He}^{1}$, Liusheng $\mathrm{Li}^{1}$, Mingxue Jiang ${ }^{2}$ \\ 1, Department of Materials Engineering, Luoyang Technology College, \\ Luoyang 471003, China \\ 2, College of Material Science \& Engineering , Xi'an University of \\ Architecture \& Technology, Xi'an 710055, China
}

\begin{abstract}
:
Effects of some kinds of alumina on physical properties of high-purity andalusite based refractory were studied, and, effects of type and amount of added alumina on phase composition and microstructure of the refractory were investigated by XRD and SEM. The results revealed that the sintering property of the refractory sample without added alumina was better than that of one with added alumina, whereas the effect of a selected sample of added alumina on the sintering property of the high-purity andalusite based refractory was related to the purity and activity of the added alumina sample. The $\mathrm{SiO}_{2}$ glass phase originated from the decomposed andalusite aggregate cannot wholly react with added alumina to form secondary mullite. Moreover, when the quantity of added alumina amounted to about 15\% (mass percent), more extensive secondary mullitization and greater expansion will be observed in the experimental sample.
\end{abstract}

Keywords: andalusite based refractory; alumina; secondary mullitization; physical properties

Andalusite $\left(\mathrm{Al}_{2} \mathrm{O}_{3} \quad \mathrm{SiO}_{2}\right)$ is a member of the alumino-silicate minerals. Because of having excellent high temperature volume stability, mechanical strength, thermal shock resistance and creep resistance, the refractories made from andalusite have been used in many industrial fields, such as metallurgical industry, building materials industry, and others ${ }^{[1-7]}$. Although mullitization and sintering properties of andalusite concentrate powder have been studied by some scholars ${ }^{[8-11]}$, the reports about applied research of alumina in high-purity andalusite based refractory have not been seen. Aiming at the development of high performance andalusite based refractory products, this paper probes the effects of the addition of selected samples some of alumina on microstructure, phase composition and specified physical properties of high-purity andalusite based refractory (hereafter abbreviated to HPABR).

\section{Experimentation}

The chemical composition of main raw materials adopted in experiments are listed in Table 1. The high-purity andalusite listed was from South Africa, and its coarse concentrate had been calcined before being used, the calcined condition was $1500^{\circ} \mathrm{C} \times 3 \mathrm{~h}$. Concerning the added alumina raw materials, all of those listed except 
active alumina are less than $0.044 \mathrm{~mm}$ in particle size, whereas active alumina is a micropowders that has a particle size of less than $5 \mu \mathrm{m}$. The experiment included two parts. At first, equivalent amount of sintered alumina, fused brown corundum, bauxite based corundum and active alumina were added into the matrix of samples respectively, and the effects of different samples of alumina on physical properties of HPABR were investigated. Second, a selected sample of alumina was fixed, and the effects of this addition of the fixed alumina on physical properties of HPABR were further investigated. By way of adopting an oil press, green bodies of all samples were formed under pressure of $200 \mathrm{MPa}$. After being dried for about 24 hours, the green bodies were fired in an electric furnace under $1500^{\circ} \mathrm{C}$ and for 3 hours of soaking time.

Table.1 chemical composition of main raw materials (\%)

\begin{tabular}{clllllllr}
\hline Raw material & $\mathrm{SiO}_{2}$ & $\mathrm{Al}_{2} \mathrm{O}_{3}$ & $\mathrm{Fe}_{2} \mathrm{O}_{3}$ & $\mathrm{TiO}_{2}$ & $\mathrm{CaO}$ & $\mathrm{Mg} 0$ & $\mathrm{~K}_{2} \mathrm{O}$ & $\mathrm{Na}_{2} \mathrm{O}$ \\
\hline Andalusite & 38.60 & 59.39 & 1.01 & 0.03 & 0.22 & 0.23 & 0.15 & 0.06 \\
Sinerted alumina & 0.18 & 99.41 & 0.12 & - & 0.15 & 0.13 & 0.05 & 0.09 \\
Fused brown corundum & 0.63 & 95.42 & 0.37 & 2.23 & 0.13 & 0.08 & 0.31 & - \\
Bauxite based corundum & 0.29 & 98.59 & 0.16 & 0.42 & 0.10 & - & 0.07 & - \\
Active alumina & 0.12 & 99.52 & 0.08 & - & 0.06 & 0.05 & - & 0.03 \\
\hline
\end{tabular}

After the fired samples cooled down, the bulk density, porosity, crushing strength, firing expansion and refiring expansion of them were tested. The creepage of a part of the samples were also tested, and microstructure of the selected samples were observed by SEM. In addition, the phase composition of a part of the samples were tested by XRD, and the instrument used was Japanese $\mathrm{D} / \mathrm{max}-3 \mathrm{c}$ model diffractometer. When the diffractometer tested samples, it had $35 \mathrm{KV}$ working voltage and $40 \mathrm{~mA}$ working current, and scaned the samples by CuK ${ }_{a} 1$ ines.

\section{Results and Discussion}

\subsection{Effects of different kinds of alumina added in matrix on properties of HPABR}

Effects of different samples of alumina added to the matrix on bulk density, porosity, crushing strength of samples are shown in Fig.1 and Fig.2 respectively, effects of the samples with alumnia on firing expansion and refiring expansion of the samples are shown in Fig.3. and the phase composition of fired samples are listed in Table 2. The samples were: Symbol $\mathrm{J}_{0}$ without added alumina, $\mathrm{J}_{1}$ with sintered alumina added, $\mathrm{J}_{2}$ with fused brown corundum added, $\mathrm{J}_{3}$ with bauxite based corundum added and $\mathrm{J}_{4}$ was the

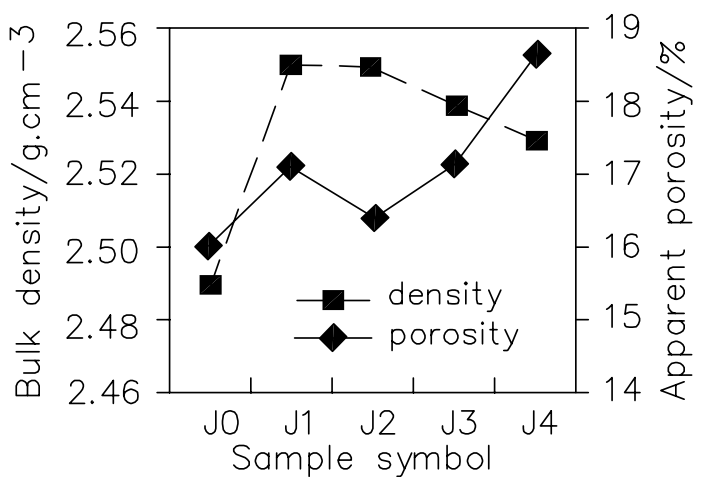

Fig.1. Bulk density and apparent porosity of fired samples added with different alumina sample with active alumina added.

Fig.1 and Fig.2 show that adding different samples of alumina in matrx had 
different effects on sintering property of HPABR sample. As shown in the figures, sample $\mathrm{J}_{0}$ without added alumina had better sintering property, while the sintering property of other samples added with alumina was inferior to sample $\mathrm{J}_{0}$. In addition, the sintering property of sample $\mathrm{J}_{1}$, which was added with sintered alumina, almost was equivalent to that of sample $\mathrm{J}_{3}$ added with bauxite based corundum, whereas the sintering property of sample $\mathrm{J}_{2}$ added with fused brown corundum was better than that of sample $J_{1}$ and $J_{3}$, and, the sintering property of sample $\mathrm{J}_{4}$ added with active alumina was inferior to that of sample $\mathrm{J}_{1}$ and $\mathrm{J}_{3}$.

The causes of the results mentioned above should lie in differences in purity, activeness of added alumina, and in difference in intensity of secondary mullitization effect caused by these factors. The reason why sample $\mathrm{J}_{0}$ without added alumina had a better sintering property is that, when andalusite in sample $\mathrm{J}_{0}$ was heated under $1300^{\circ} \mathrm{C} \sim 1500^{\circ} \mathrm{C}$ and

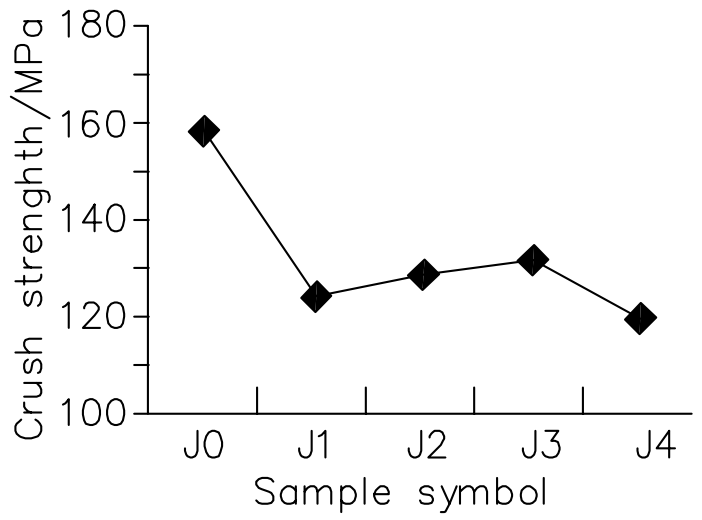

Fig.2. Cold crushing strenghth of fired samples added with different alumina

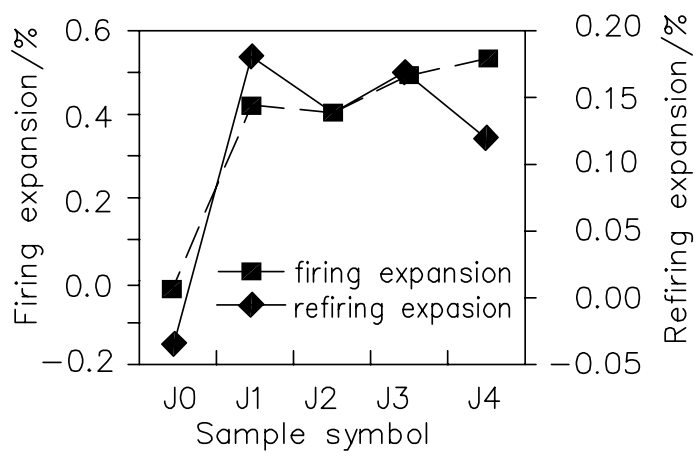

Fig.3. Firing and refirinng linear change of samples added with different alumina transformed into mullite with a capillary network simultaneously, about 15\% 19\% (of andalusite mass) silica-rich glass would be formed in it ${ }^{[11]}$, the silica-rich glass originating from andalusite mullitization would react with other impurities in sample $\mathrm{J}_{0}$ and form low melting liquid phase further, consequently, the sintering state of sample $\mathrm{J}_{0}$ was improved. Instead, in those samples added with various alumina, because added alumina would react with the silica glass originating from andalusite mullitization to form secondary mullite. While this reaction was followed with volume expansion of $7 \% \sim 8 \%{ }^{[12]}$, which hindered sintering of the samples. Therefore, it was conclude that the sintering property of the samples with various alumina added was inferior to that of sample $\mathrm{J}_{0}$. The firing expansions of samples shown in Fig.3 also prove this conclusion that except for sample $\mathrm{J}_{0}$, the firing linear changes of all the other samples showed volume expansion, and only sample $\mathrm{J}_{0}$ showed volume shrinkage. It was concluded that sintered alumina and bauxite based corundum had equivalent content of impurities (Table 1) and the same fineness of powders, so they had equivalent reaction activity, consequently sample $\mathrm{J}_{1}$ and $\mathrm{J}_{3}$ had equivalent sintering property. That sample $\mathrm{J}_{4}$ had inferior sintering property was because active alumina added to it resulted in a more intense secondary mullitization effect under high temperature, thus it was more difficult for sample $\mathrm{J}_{4}$ to be sintered. This can be verified by the firing expansion of fired samples shown in Fig.3 and the phase composition of fired samples shown in Table 2. Sintering property of sample $J_{2}$ was better than that of 
sample $\mathrm{J}_{1}$ and $\mathrm{J}_{3}$, but mullite content in sample $\mathrm{J}_{2}$ was less, this might probably relate to higher content of alkali oxide impurities in fused brown corundum. Wang Jinxiang et al has researched effect of $\mathrm{K}_{2} \mathrm{O}$ on phase composition of sintered bauxite based material ${ }^{[13]}$. His research results showed that increase of $\mathrm{K}_{2} \mathrm{O}$ content in the material would not only result in increase of glass phase in it, but at the same time, also cause decomposition of mullite in it.

Table.2 Phase composition of fired samples added with different alumina

\begin{tabular}{|c|c|c|c|c|c|}
\hline Minerals & $\mathrm{J}_{0}$ & $\mathrm{~J}_{1}$ & $\mathrm{~J}_{2}$ & $\mathrm{~J}_{3}$ & $\mathrm{~J}_{4}$ \\
\hline Andalusite & 16 & 18 & 29 & 15 & 19 \\
\hline Mullite & 64 & 67 & 56 & 66 & 70 \\
\hline Corundum & - & 1 & - & 4 & - \\
\hline Glass & 20 & 13 & 15 & 12 & 11 \\
\hline
\end{tabular}

In addition, the diffraction intensity of the strongest peak (110) of andalusite in fired sample $\mathrm{J}_{0} \sim \mathrm{J}_{4}$ was shown in Fig.4. It can be seen from Fig.4 and Table 2 that, compared with other fired samples, fired sample $\mathrm{J}_{2}$ contained much andalusite mineral. This is in contradiction with research conclusions of other researchers ${ }^{[9-}$ 10], who found that existence of impurities, especially alkali impurities, would cause further decomposition of andalusite. The causes of these results need to be probed further.

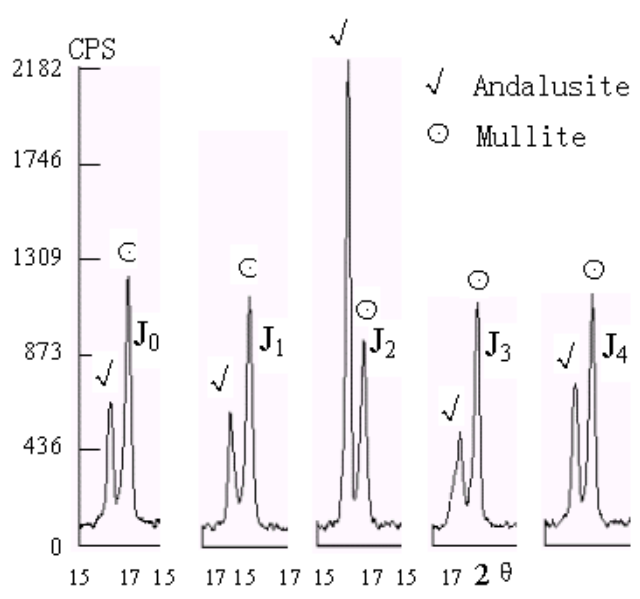

SEM photographs of matrix area of

Fig.4. XRD patterns of sample $J_{0} \sim J_{4}$ fired sample $\mathrm{J}_{0}, \mathrm{~J}_{1}$ and $\mathrm{J}_{4}$ are shown in Fig.5. By way of comparision and analysis, it can be seen that all gaps between grains in matrix area of sample $J_{0}$ are filled with glass phase, and it appears similar grains dispersively existing in glass matrix. Whereas SEM photographs of sample $\mathrm{J}_{1}$ and $\mathrm{J}_{4}$ manifest the borders between grains in the matrix area as more vague because of the formation of secondary mullite, which was caused by the reaction between added alumina and silica glass originating from andalusite decomposition. It could be said that secondary mullite formed a bridge-link between original grains in the matrix area of sample $\mathrm{J}_{1}$ and $\mathrm{J}_{4}$, especially in matrix area of sample $\mathrm{J}_{4}$, the bridge-link formed by secondary mullite appears to be tighter.

\section{2..2 Effects of amount of added alumina on properties of HPABR}

\subsubsection{Definition of amount of alumina added in the matrix}


In the light of experimental results presented above, it was decided that active alumina would be used for studying further effects of varying the amount of added alumnia on properties of HPABR. In order to promote the generation of silica glass from mullitized andalusite to be transformed into secondary mullite, it is necessary to control the appropriate amount of alumina existing in the sample. As stated above, when andalusite crystal wholly was transformed into mullite with a capillary network under high temperature, about 15\% 19\% (mass percentage) of silica glass would be formed, however most of the silica glass iz would be trapped in the capillary network of the neoformed mullite, whereas only about $3.5 \%$ (mass percentage) of the silica glass would not be accommodated in the capillary network and would be squeezed out. This "free" silica glass expelled from the neoformed mullite grains easily reacted with added alumina to form secondary mullite. Therefore, if $18 \%$ silica glass originated from mullitization of andalusite powder and $3.5 \%$ silica glass came from being expelled from mullitized andalusite aggregate and these combined amounts of silica glass could participate in the reaction with added alumina to form

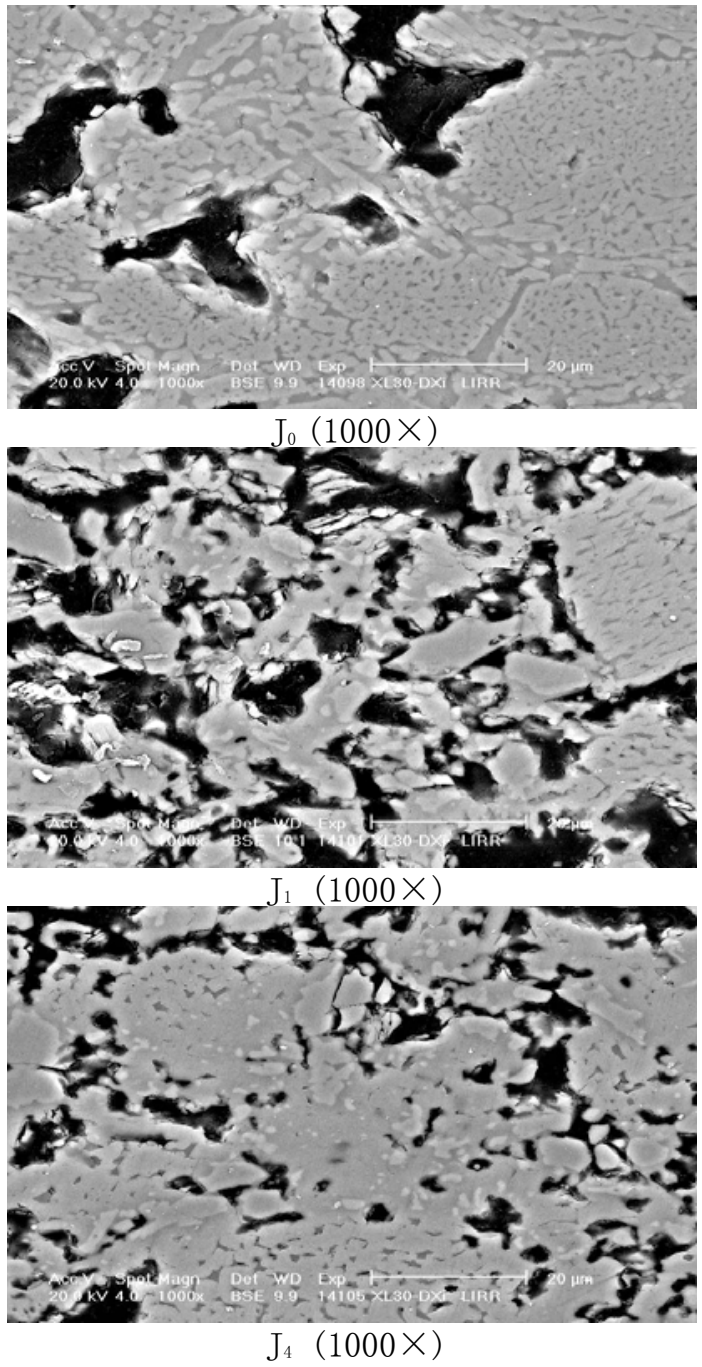

Fig.5 SEM photographs of matrix of sample $J_{0} \sim J_{1}$ and $J_{4}$ secondary mullite, then the amount of alumina added in a sample can be determined or defined by the total amount of andalusite aggregate and powder in the sample. On this account, the formula of each sample with a different amount of added active alumina was designed as shown in Table 3, the amount of active alumina added in sample $\mathrm{J}_{6}$ was approximately equal to amount $(\approx 16 \%)$ of alumina needed for making silica glass expelled from mullitized andalusite aggregate and powder to react with it and to form secondary mullite.

Table. 3 Formula of samples added with alumina

\begin{tabular}{ccccc}
\hline Raw material & $\mathrm{J}_{5}$ & $\mathrm{~J}_{6}$ & $\mathrm{~J}_{7}$ & $\mathrm{~J}_{8}$ \\
\hline Andalusite aggregate & 60 & 60 & 60 & 60 \\
Andalusite powder & 28 & 23 & 18 & 13 \\
Active alumina & 10 & 15 & 20 & 25 \\
Bond & 2 & 2 & 2 & 2 \\
\hline
\end{tabular}




\subsubsection{Effects of addition amount of active alumina on properties of HPABR}

Effects of addition amount of active alumina in the matrix on bulk density, porosity and crushing strenghth of HPABR sample are shown in Fig.6 and in Fig.7 respectively, and effects of it on firing expansion and refiring expansion of the samples are shown in Fig.8.

It can be seen from Fig.6 that the bulk density of the samples increased with increment of additional amount of active alumina micropowders; and, that there was not much difference in porosity amongst other samples except sample $J_{6}$, and only the porosity of sample $J_{6}$ was a little higher. The change of crushing strength was from the former decrement to latter increment, which took sample $\mathrm{J}_{6}$ as a turn point (Fig.7). This also was in accordance with the firing expansion case of samples. Compared with sample $\mathrm{J}_{7}$ and $\mathrm{J}_{8}$, sample $\mathrm{J}_{6}$ had larger porosity and lower crushing strength strenghth. It was probably because the amount of active alumina added in sample $\mathrm{J}_{6}$ correctly resulted in both the largest secondary mullitization effect and having no remainder of active alumina micropowders to impel further sintering of sample $\mathrm{J}_{6}$. Because of the lower amount of active alumina micropowders in sample $J_{5}$, the secondary mullitization effect in it was less than that in sample $\mathrm{J}_{6}$. Thus, sample $\mathrm{J}_{5}$ showed smaller firing expansion, and at the same time, as a result of much more glass phase present amongst mullite grains and firmly sticking them together, it also showed higher crushing strength. Table 4 shows phase composition of each fired sample, which was obtained by way of XRD analysis (XRD patterns are omitted). It can be seen from Table 4, that there was a certain amount of corundum phase in sample $\mathrm{J}_{7}$ and $\mathrm{J}_{8}$, and the amount of corundum existing in them was approximately equal to the amount gained by subtracting alumina amount $(\approx 16 \%)$ consumed in secondary mullitization process from the amount of active alumina added in them initially.

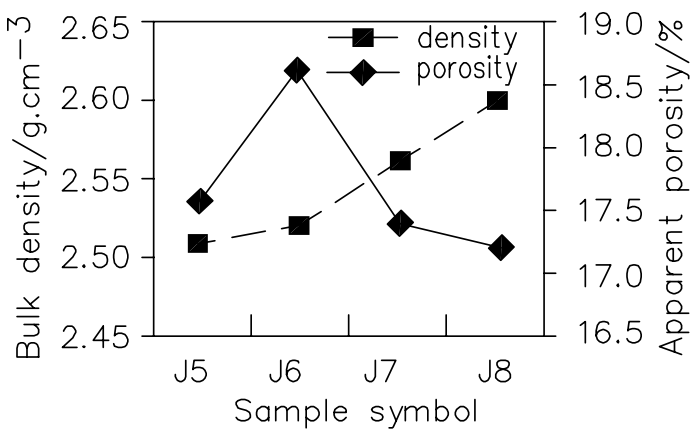

Fig.6 Effects of addition amount of active alumir on bulk density and apparent porosity of fired samples

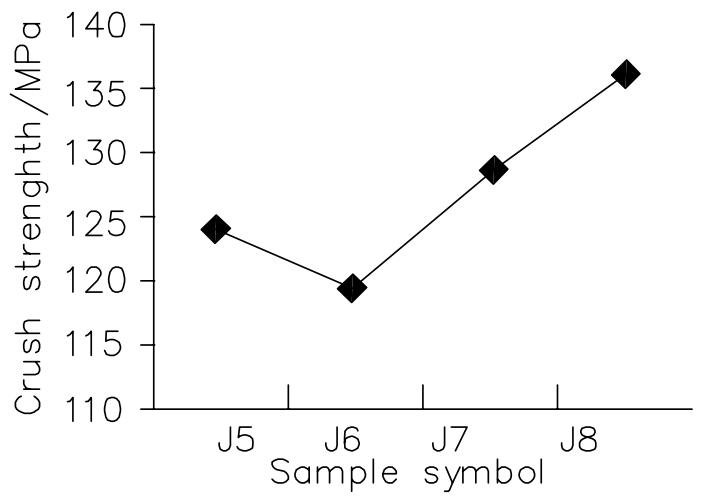

Fig.7 Effect of addition amount of active alumina on cold crush strenghth of fired samples

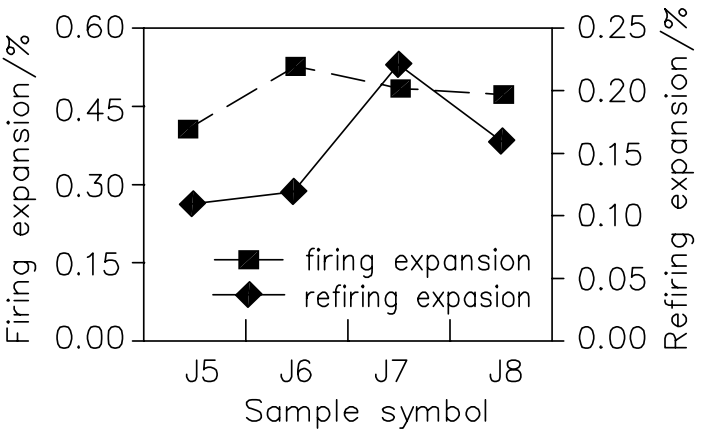

Fig.8 Effects of addition amount of active alumina on firing and refiring linear change of samples 
Table.4 Phase composition of fired samples with different addition amount of active alumina powder

\begin{tabular}{ccccc}
\hline Mineral & $\mathrm{J}_{5}$ & $\mathrm{~J}_{6}$ & $\mathrm{~J}_{7}$ & $\mathrm{~J}_{8}$ \\
\hline Andalusite & 16 & 17 & 19 & 10 \\
Mullite & 65 & 68 & 67 & 69 \\
Corundum & - & - & 2 & 9 \\
Glass & 18 & 13 & 11 & 11 \\
\hline
\end{tabular}

The experimential result mentioned above proves that the inference made in the preceding paragraph is correct, that is, in the sintering process of andalusite based products, most of the whole silica glass $(\approx 18 \%)$ originated from the mullitization of andalusite powder and a little silica glass $(\approx 3.5 \%$ ) was expelled from the mullitized andalusite aggregate which participated in the secondary mullitization reaction, whereas the silica glass trapped in capillary crevices in initial mullite grains could hardly react with added alumina to form secondary mullite. Therefore, if the intent is to avoid corundum phase arising in sample, the additional amount of alumina should be defined in the light of amounts of andalusite aggregate and powder in sample. Fig.9 has shown the effect of addition amount of active alumina micropowders on creepage of fired samples, the condition of creep experiment was $1400^{\circ} \mathrm{C} \times 50 \mathrm{~h}, 0.2 \mathrm{MPa}$. It can be seen that, increasing the amount of added alumina, the creepage of fired samples decreased at first, then increased again, and, the samples with 15\% 20\% added alumina had lower creepage. Although presently there is a research conclusion ${ }^{[14]}$ that indicates the multiphase material composed simultaneously of mullite and corundum had better creep resistance than the monophase material composed only of mullite or corundum, however, this was only as far as the material nearly without glass phase is concerned. So far as this experimental work is concerned, the fired samples contained a significant quantity of glass phase (Table 4), so the conclusion mentioned above is not suitable to this

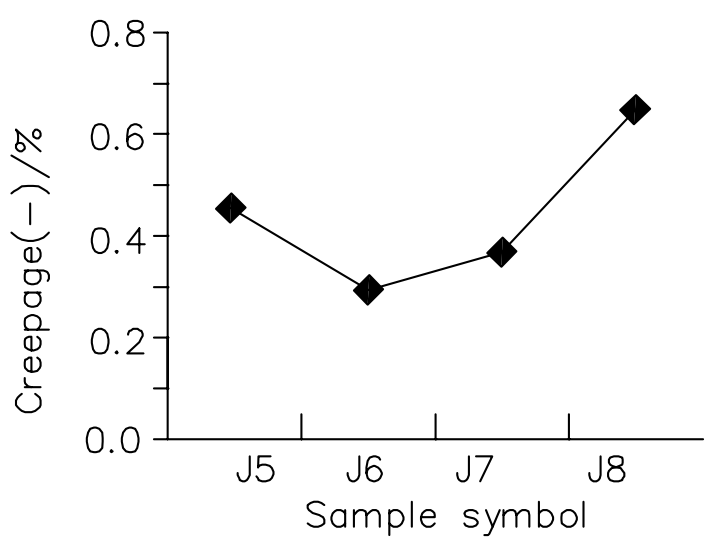

Fig.9 Effect of amount of alumina added on creepage of samples

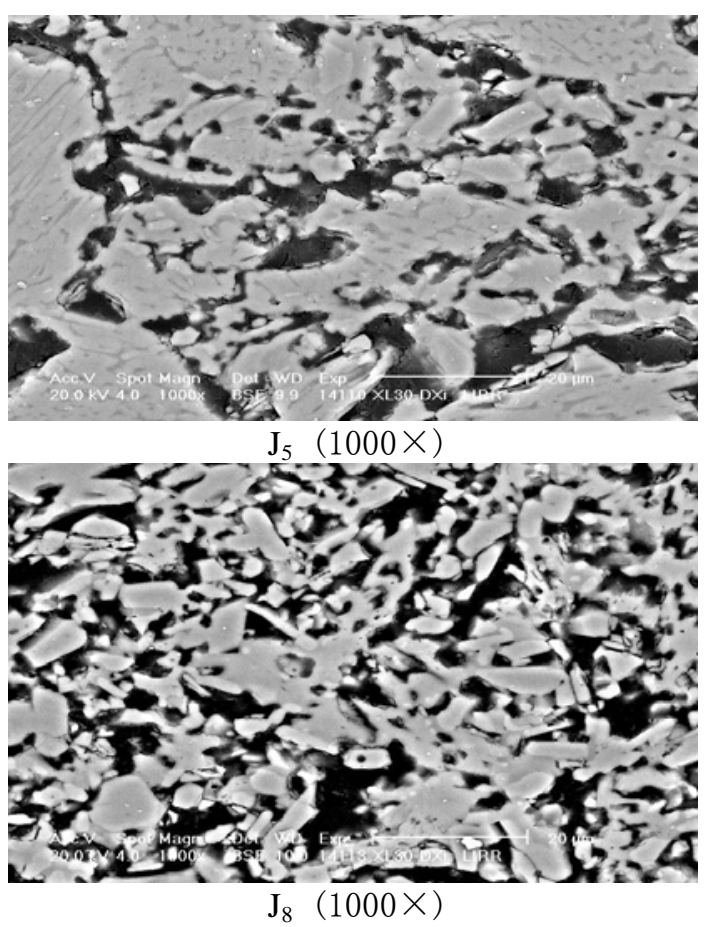

Fig.10 SEM photographs of matrix of sample $J_{5}$ and $J_{8}$ 
experimental result. Contrarily, because of bad creep resistance of granular corundum grains, in the glass phase existing in grain borders, granular corundum grains would slide easily when they bear a compression stress for long time under high temperature, and consequently would result in a larger creep effect. Fig.10 shows SEM photographs of matrix area of fired sample $J_{5}$ and $J_{8}$. Apparently, many granular corundum grains dispersively existed in the matrx of sample $\mathrm{J}_{8}$, while there were less granular corundum grains in the matrx of sample $\mathrm{J}_{5}$, and the products generated in secondary mullitization in it made the joining degree between grains higher.

\section{Conclusion}

1. The effect of various samples of alumina powder on sintering property of HPABR is relevant to purity and activeness of it. The sintering property of samples with added active alumina micropowders is inferior, that of samples with added fused brown corundum is better, while that of samples with added sintered alumina or bauxite based corundum would be graded between the two above.

2. In the sintering process of andalusite based material, only about $18 \%$ silica glass originating from mullitization of andalusite powder and about $3.5 \%$ silica glass expelled from mullitized andalusite aggregate can be available to participate in secondary mullitization reaction.

3. As far as this experimental work is concerned, when the amount of added active alumina in sample is about $15 \%$, the sample had the largest secondary mullitization effect and porosity, firing expansion, and lower crushing strenghth.

4. Comprehensively taking demands of various properties of HPABR into account, we think that a suitable additional amount of alumina in it should be $10 \% \sim 20 \%$.

\section{References:}

[1] Dubreuil P. et al, Use of Andalusite Refractories in Ferrous Metallurgy, Refra. Ind. Ceram. 1999, Vol.40 (6) : 252 259

[2] R.B. Bartelink et al, Andalusite-25 years on. (A Report of the Rhino Andalusite Mines Company), 1996.9

[3] F. T. Niemeijer et al, New Refractories for Torpedo Ladles, Steel Times International, 1999, Vol.14 (6) : 38

[4] Lionel Rebouillat et al , Andalusite-Based High-Alumina Castables, J. Am. Ceram. Soc. 2002, Vol.85 (2) : 373 378

[5] Manfred Koltermann, Andalusite Bricks for Torpedo Ladles, Steelmaking Conference Proceedings, 1979, Vol.62 : 241 245

[6] YANG Zhifu.Overseas Refractory (in Chinese), 2001, (3): 32-37

[7] William H.McCracken et al, Annual Minerals Review-

Andalusite, Am.Ceram.Soc.Bull. 1997, Vol.77 (6) : 85 86 
[8] WEN Hong jie. Naihuo Cailiao (in Chinese), 1995, 29(5): 247-250

[9] LI Bowen. J. Mineral Petrol (in Chinese), 1993, 13(3): 36-41

[10] LIN Binyin. Naihuo Cailiao (in Chinese), 1990, (1): 28-32

[11] Jean-Pierre Ildefonse et al , Mullitization of Andalusite in Bricks and Castables[A]. IN: UNITECR' 97. Proc. Unified Int. Tech.Conf. on Refractories[C], New Orleans, USA:1997. 899 908

[12] He Jin-zhou et al, The Study on $\mathrm{Al}_{2} \mathrm{O}_{3}-\mathrm{SiO}_{2}$ Based Castables Containing Andalusite[J], China’s Refractories (in English), 1994, Vol.3 (2) : 14 18

[13]WANG Zetian, YAN Xingjian. Zhong Xiangchong's Select Treatise on Refractories (in Chinese). Beijing: The Metallurgy Industry Press, 1991. 236237

[14] LI Tingshou. Naihuo Cailiao (in Chinese), 1986, (3): 1-8 